\begin{tabular}{|c|c|c|c|}
\hline $\begin{array}{l}\text { OLO ROMERIO } \\
\text { NIVERSITETAS }\end{array}$ & $\begin{array}{l}\text { Escola Superior } \\
\text { de Cestäo e } \\
\text { Tecnologia } \\
\text { [iPSantarém] }\end{array}$ & & $\begin{array}{l}\text { ISSN 2029-7564 (online) } \\
\text { SOCIALINĖS TECHNOLOGIJOS } \\
\text { SOCIAL TECHNOLOGIES } \\
2012,2(2), \text { p. } 273-289\end{array}$ \\
\hline
\end{tabular}

\title{
SEEKING A SUSTAINABLE DEVELOPMENT SCOREBOARD: BEYOND THE AGENCY THEORY
}

\author{
Ilídio Tomás Lopes ${ }^{1}$ \\ School of Management and Technology, Polytechnic Institute of Santarém, Portugal, \\ email: ilidio.lopes@esg.ipsantarem.pt
}

\section{Abstract}

Purpose - the concept of Sustainable Development (SD) is embodied in complexities and intrinsic contradictions. Its boundaries are vague, deriving in an unresolved paradox. Development is, in its genesis, linked to economy features and achievements, and sustainability is traditionally associated with ecology and social progress. However, the merger of both can drive the main human freedoms. Countries and companies should monitor their sustainable development indicators using the capabilities allowed by information and communication technologies and through integrated knowledge management systems. This paper aims to provide a standard and conceptual framework for sustainable development performance analysis.

Design/methodology/approach - based on the themes and headline indicators, disclosed by the European Union and the SD indicators included in the listed companies'

$1 \quad$ Ilídio Tomás Lopes is Professor and Dean of the School of Management and Technology (Polytechnic Institute of Santarém, Portugal). Graduate in Business Administration (Technical University of Lisbon, Portugal, 1990), he obtained a Master Degree in Statistics and Information Management (New University of Lisbon, Portugal, 2001) and a PhD in Management, specialization in Accounting (University of Coimbra, Portugal, 2009). Researcher in the fields of: knowledge management, management and financial accounting, management control systems, and innovation. He is member of several scientific committees and editorial boards. Recently, he was the Conference Chair of the $7^{\text {th }}$ European Conference on Innovation and Entrepreneurship (ECIE 2012) managed by Academic Conferences International (Reading, UK) and hosted by School of Management and Technology (Santarém, Portugal).

Socialinès technologijos/Social Technologies

(C) Mykolo Romerio universitetas, 2012

(C) Mykolas Romeris University, 2012
ISSN 2029-7564 (online)

https://www.mruni.eu/lt/mokslo_darbai/st/apie_leidini/ https://www.mruni.eu/en/mokslo_darbai/st/apie_leidini/index.php 
management reports, a conceptual framework was designed. A content analysis of the sustainability reports, issued by some Portuguese listed companies, has supported our suggestion for a set of key performance indicators, through a balanced scorecard approach.

Findings - through a Balanced Scorecard approach we suggest a dynamic framework, which combines an integrated analysis at the country and corporate levels. A set of key performance indicators are also identified, aggregated and integrated in a proposed sustainability scorecard.

Research limitations - the set of key indicators included in the framework proposed are not exclusive and can be changed according to the sector and company specificities. The integrated approach that is proposed is dynamic and should be adjusted according to the information management requirements.

Practical implications - a conceptual framework was designed through a Balanced Scorecard approach. Based on the agency theory background, companies can provide a standard framework about sustainability key indicators. Management reports are improved towards a better approach between companies and their stakeholders.

Originality/value - this paper highlights the boundaries of sustainable development, their complexities, and provides a systematic framework which allows performance monitoring through a selected set of key performance indicators. This dynamic framework can be adjusted in order to reflect the continuous achievements and insights in this scientific field.

Keywords: sustainability, agency theory, information dissemination, scorecard, performance indicators.

Paper type: Conceptual paper.

\section{Introduction}

The quality of information disclosed to stakeholders has driven several researches in the scope of management reports utility. Based on the Contingency (Reid and Smith, 2000; Thomas, 1991), Institutional (Chapman et al., 2009; DiMaggio and Powel, 1991) and Legitimacy (Dowling and Pfeffer, 1975; Guthrie et al., 2004) theories, the information dissemination is stilted by multiple stakeholder's expectations and requirements. Thus, several restrictions on the information dissemination can be explained in the framework of agency theory, especially the dissemination of non-mandatory information. The new management approaches require a new set of indicators, duly integrated in a cause and effect chain, which allows companies and individuals an integrated outlook at the macro and micro economic levels.

Development has been broadly identified in economic reports and analysis as growth of Gross National Product (GNP), even connected to the rise in personal incomes, connected to industrialization and technological advances, and pursuing the 
social welfare. It can be seen as a process of expanding the real freedoms of a human being (Sen, 1999). These freedoms are also dependent on other key determinants such as social and economic facilities, political and civil rights. Industrialization and technological advances are the key insights to expand those human freedoms.

Sustainable Development (SD) crosses the boundaries of economy, environment and society (Searcy et al., 2005:38). In this conceptual analysis, we linked it to society knowledge acquisition, transformation and dissemination towards economic and social growth achievements (Nonaka and Takeuchi, 1995). The main researches on the topic have put the concept at macro and microeconomic levels, although separately explored. Several methods have been followed in this scientific field, some of them based on critical theory (Milne et al., 2009; Springett, 2003), and others based on the development of conceptualized models and frameworks (Jabareen, 2008; Searcy et al., 2005; Garvare and Isaksson, 2001; Bergstrom and Dobers, 2000).

In our approach, SD is strongly linked to Knowledge Based Economy (KBE), as determinative of deep changes in the behaviours of individuals, teams and organizations. These knowledge assets have been used to reach sustainable standards of development and growth (Lopes et al., 2005). The advent of a new economic paradigm is embedded in the need to manage these new resources. The emerging new business models, built up in a global economy throughout complex networks, have their hard nucleus in basic activity of the modern value chain: the innovation and knowledge management processes. Many companies, investing in the most recent technologies, tried to implement and develop solutions in order to achieve sustainable positions through their ability to acquire, develop and transform knowledge into expertise. The same approach has been followed at national levels, searching for an old and unresolved paradigm: the achievement of a social sustainable welfare standard.

At a microeconomic level, the production and dissemination of sustainability reports has contributed to a greater awareness of the significance of SD. As stated by Milne et al. (2009), individuals and companies, through organized initiatives and processes, are responding by demanding changes in behaviours, consistent with environmental and social responsibility. Those individuals and companies are usually requested to disseminate to their stakeholders information about environmental and social activities. These reports are mandatory for the listed companies, with the objective to mitigate the conflicts derived from the information asymmetry. Otherwise, the assumptions of agency theory have resulted, in this scope, in emerging gaps between the information dissemination and the stakeholder's expectations and requirements. However, for listed companies, when environment and social responsibility activities are performed, companies manage those disclosures as a source of potential future returns.

This conceptual paper aims to identify the boundaries of sustainability and its application at the country and corporate levels. With this approach we launch the basis for a conceptual scorecard as a dynamic tool in order to monitor the sustainability performance at country and corporate levels. 


\section{Information Management Towards Performance Analysis}

\subsection{The boundaries of the agency theory}

Agency theory has been incorporated in multiple scientific fields, particularly in accounting (Demski and Feltham, 1980), in economics (Spence and Zeckhouser, 1971), marketing (Basu et al., 1985), in political science (Mitnick, 1986), in finance (Fontrodona and Sison, 2006; Fama, 1980), in behaviour and organizational culture (Kulik, 2005; Eisenhardt, 1985; Kosnik, 1987) and in sociology (Shapiro, 2005; White, 1985). However, controversy over its usefulness, applicability and validity remains to this day. It was developed during the 60 s and early 70 s of the 20th century, by several economists, including Arrow (1971) and Wilson (1968). It translates the problem of attitude towards risk either by individuals and/or by groups (Ross, 1973). The differentiation of objectives inherent to those parties that leads their attitude is also different. Those are relations between the principal and agent, metaphorically supported by contract-oriented behaviour of parties who take different attitudes towards risk (Jensen and Meckling, 1976).

According to Eisenhardt (1989), agency relationship arises between two or more parties in a designated agent, acting for the other, called the main field, in a particular decision. Acting for both parties in favour of their own interest, the principal conducts its action to minimize costs; the agent-in order to minimize their action. According to Jensen and Meckling (1976), the agency costs correspond to the sum of the costs of monitoring by the principal (associated with the incentives of the agent and the monitoring process of their activity), expenses of the undertaking by the agent (associated with resources spent by the agent to compensate the principal for inappropriate actions) and residual losses (associated with the degree of divergence between the agent's decisions and the decisions that potentially maximize the wellbeing of the principal).

\subsection{The link between agency theory and knowledge management activities}

The link between agency theory and theories of knowledge management (capture, creation, processing and dissemination) is the importance that information and knowledge have in organizations, particularly in the conversion modes identified by Nonaka and Takeuchi (1995). Both agency theory and contingency theory (Laurence and Lorsch, 1967; Chandler, 1962) are based on information. Those theories assume the rationality of individuals, the efficiency in processing information and thus its distribution is asymmetric across organizations. Two contributions of agency theory in the scope of knowledge management can be identified: 1) Associated with the evidence that the processing of information as a commodity has an associated cost in their creation, so it can be purchased (Shapiro and Varian, 1999); and 2) Associated with risk management and its impact in the relation between suppliers and users of information. In volatile and increasingly complex environments, the availability of information and the ability 
to obtain and manage your risk accordingly, influences the agency contract. The focus should be oriented towards information systems, towards uncertainty in the results and to the intrinsic risk, according to McGrath et al. (1981), a forecasting process based on knowledge.

As in agency theory, within the knowledge management process, some sources of divergences can be also identified, most of them pronounced in the processes of socialization and externalization (Nonaka and Takeuchi, 1995). Thus, discrepancies between organizational conditions that promote the formation of this knowledge and economic conditions allow the appropriation of value through processes of exploration / exploitation (Crossan et al., 1999).

The distinction between implicit and explicit information represents another link between that theory and the creation of information or knowledge. As already mentioned, while agency theory focuses its analysis on the costs associated with the conversion of those types of information conversion, knowledge management focuses on the mechanisms and contexts that enable or detract that conversion process. The conversion mechanisms and control of information into knowledge (difficult to imitate) represents an important strategic effort, which can lead to the achievement of key competitive advantages. The symbiosis between cognitive processes and social interaction along the steps of intuition, interpretation, integration and institutionalization (Crossan et al., 1999) reduces the ambiguity objectively.

Traditionally, agency theory incorporates certain control mechanisms (e.g. culture) based primarily on what happens within organizations. Knowledge management, in their view of capturing and transferring knowledge, emphasizes the relevance of external control mechanisms (such as the institutionalization of communities of practice, as expressed by Wenger (2000). It provides training and development that increase the absorptive capacity (Lane and Lubatkin, 1998) of individuals by encouraging them to share and to reinforce internal and external networks.

\subsection{Information disclosure: the generic theories}

The paradigm of the usefulness of information for decision-making is now one of the key issues in the designing process towards information dissemination to their stakeholders. The profound changes that have occurred in the economies in general and in particular business models require information to be disclosed in a timely manner and meeting the expectations of its users. However, many are the factors that determine the type, timing and intensity with which this information is disseminated.

There are several theories that have explained the various factors that influence disclosure: contingency theory (Reid and Smith, 2000, Thomas, 1991), institutional theory (Chapman et al., 2009; DiMaggio and Powell, 1991) and legitimacy theory (Dowling and Pfeffer, 1975; Guthrie et al., 2004). However, it is our understanding that the factors that determine the dissemination of information result in symbiosis between them all, given the complexity of the business that we know today. Any of these theories have their basis in a social contract between the company and its stakeholders, creating 


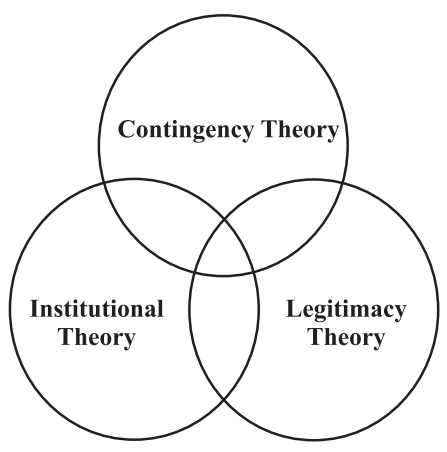

Fig. 1. The information disclosure theories

internal mechanisms to respond to changes that occur in the environment.

The contingency theory assumes a theoretical perspective that contingencies such as size, uncertainty and risk, technology and environmental pressures, affect the organization's development and operating processes. Thus, organizations cannot develop a standard framework to plan, organize and control their own activities. The second theory (institutional) considers that organizations should adapt to external expectations, so there are external pressures to implement appropriate practices to disseminate information. The fact that organizations

tend to implement the same structures and practices in time, as a response to social requirements, is designated in the literature as institutional isomorphism (DiMaggio and Powell, 1991). The theory of legitimacy is based on the notion of a social contract between the reporting entity and the society in which it operates (Guthrie et al., 2004). The dissemination of information is one way to relieve social pressure and legitimize their organizational activities.

The usefulness issue of information management has a diffuse scope, based on multiple drivers: the type of information user, their information needs, the emerging pressure from the capital markets, the changes occurring in the environment in which organizations develop their activities and even regulatory requirements, often resulting from political decisions. Indeed, we cannot link a particular theory to the entities and stakeholders' behaviours, regarding the dissemination of information. Those theories have specific determinants that embody the individual and collective behaviours. As illustrated in Fig. 1, those behaviours derive from the symbiosis assumptions that are inherent to each particular theory.

\section{The Boundaries of Sustainability}

The conceptual world of development aggregates, according to Jabareen (2008), seven distinct concepts and derives in an ethical paradox between sustainability and development. In fact, sustainability has several concepts and meanings in its theoretical foundation. It is embedded in a fluid mix of interrelations, which is the natural genesis of freedom, as argued by Sen (1999). The next figure will focus on an integrated overview about the sustainable development boundaries and their linkages with the unresolved paradox (sustainability can inhabit, independent of the environments and ideologies). Defining what should be sustained is, in its genesis, a complex process, embodied in controversial approaches, and usually identified as a source of contradictions (Jabareen, 2008, 2004; Redcliff, 1987). 
This figure evidences those contradictions (Redcliff, 1987) and points out the interrelations between multiple concepts, deriving in a continuous and controversial ethical paradox (Jabareen, 2008). Traditionally associated with ecology, sustainability aggregates several domains, apparently contradictory, such as economic growth, social inclusion or even climate changes and renewable energies. Development is, in itself, associated with economic features and interests. And, from

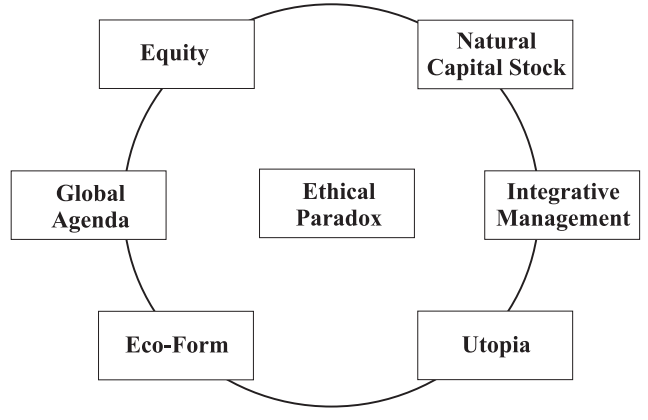

Source: Jabareen (2008:188)

Fig. 2. A conceptual framework for of sustainable development the merger of both (economic development and environmental protection), derives the paradox. Hence, the equilibrium between those pillars are affected by human behaviours (individual and collective) and actions. Interlinked with that paradox, SD aggregates other concepts (Jabareen, 2008) as 1) natural capital stock (tangible assets of development);2) equity (its social dimension); 3) eco-form (the ecological design and human spaces); 4) integrative management (the merger of economic, environmental and social issues); 5) utopianism (the desired human habitats); and 6) political global agenda (the new global disclosure towards sustainable development).

Sustainable Development is a continuous process by combining three different structural blocks of development: Economy; Environment and Society. Gross Domestic Product (GDP) does not reflect, anymore, the SD overview and new performance indicators should be integrated in a dynamic framework which, on a feasible basis, can capture the changes in those three structural pillars. Organizations like OECD and Eurostat, have defined the boundaries of sustainability (Climate change and energy, consumption and production, demographic changes, partnership, governance, natural resources, public health, social inclusion, socioeconomic development and transport) and have created a list of more than 100 indicators (Growth rate in GDP per capita, resource productivity, people at-risk-of-poverty, employment rate of older workers, health life years, greenhouse gas emissions, renewable energy, energy consumption of transport, fish catches out of biological limits and others) with the objective to promote integrated overview, both at a macro and micro level. In this paper, we will use some of the headline indicators in order to illustrate the European scenario in terms of sustainability headlines.

The transformation process towards SD achievement also depends, from an important degree, on the use of the new technologies, especially the information and communication technologies (Mohamed et al., 2010). Some indicators suggest that besides expressing the level of integration of the citizens and countries, they equally express the quality of integration in the knowledge economy. We accept that knowledge 
can be codified and then stored in a computerised system to be made available on demand. Thus, the main purpose of knowledge management and its role in the sustainable development building up process is the acquisition, capture, transformation, access, diffusion and re(use) of knowledge (Von Krogh et al., 2000; Nonaka and Takeuchi, 1995 ) by individuals and communities (broadly, the entire society). Those activities can be more efficient, depending on the context that allows and facilitates their development, and also depending on the human behaviours changes. Hence, SD is broadly defined as "the process to reach a steady state where both humanity and nature thrive" (Garvare and Isaksson, 2001:12) or as the process to meet the needs of the present without compromising the ability of future generations to meet their own needs (WCED, 1987).

\subsection{Sustainability at a macroeconomic level}

The deep transformation verified in the economic, environment and social development, requires a framework, which easily translates the real status of the SD. The need to capture the changes operated in this domain has been one of the main concerns in the achievement of a global development pointer. Similarly to the approaches followed in the Knowledge Economy analysis, the systematic use of an index system can, on a reliable basis, measure the state of the art for each economy.

The framework followed by Eurostat (2010) in the field of SD aggregates eleven key indicators, integrated in nine (A to I) different themes. Table 1 shows the corresponding themes and indicators, some of them used in this paper, in the scope of empirical evidence.

Table 1. Sustainable development indicators

\begin{tabular}{|l|ll|}
\hline \multicolumn{1}{|c|}{ Theme } & \multicolumn{2}{c|}{ Headline indicator } \\
\hline A. Socio-economic development & 1. & Growth rate of real GDP per capita \\
\hline $\begin{array}{l}\text { B. } \text { Sustainable consumption and } \\
\text { production }\end{array}$ & 2. & Resources productivity \\
\hline C. Social inclusion & 3. & People at-risk-of-poverty or social exclusion \\
\hline D. Demographic changes & 4. & Employment rate of older workers \\
\hline \multirow{2}{*}{ E. Public health } & $\mathbf{5 .}$ & $\begin{array}{l}\text { Healthy life years and life expectancy at birth, by } \\
\text { gender }\end{array}$ \\
\hline \multirow{2}{*}{ F. Climate change and energy } & 6. & Greenhouse gas emissions \\
\cline { 2 - 3 } G. Sustainable transport & 7. & $\begin{array}{l}\text { Share of renewable energy in gross final energy } \\
\text { consumption }\end{array}$ \\
\hline \multirow{2}{*}{ H. National resources } & $\mathbf{8 .}$ & Energy consumption of transport relative to GDP \\
\hline \multirow{2}{*}{ I. Global partnership } & 9. & Common bird index \\
\cline { 2 - 3 } & $\mathbf{1 0}$. & $\begin{array}{l}\text { Fish catches taken from stocks outside safe biological } \\
\text { limits }\end{array}$ \\
\hline
\end{tabular}

Source: Adapted from Eurostat (2010) 
From Table 1, we have selected a sample by convenience of four headline indicators, namely the indicators: Growth rate of real GDP per capita; resources productivity; people at-risk-of-poverty or social exclusion; share of renewable energy in gross final energy consumption. Then, we crossed the growth rate of real GDP per capita with the other three indicators, in order to obtain an overview of the European scenario in some structural themes. The same approach can be followed for all indicators stated in the table above. Complementary, we tried to evidence some of the contradictions set out by Jabareen (2008), in particular between Growth rates of GDP and Renewable energies and Social exclusion.

\subsection{Sustainability at a microeconomic level}

Sustainability, at a micro or corporate level, can be understood, similarly to the approach followed at a country level, as value creation process towards the long range achievements (turnover and other financial features). It is also aligned with knowledge management and the processes used to create, capture, transform and disseminate it to stakeholders, most of them included in the sustainability reports. Derived from the minds of workers and their values (Davenport and Prusak, 1998), knowledge is recognized as information, beliefs and commitment (Nonaka and Takeuchi, 1995). As stated by Davenport and Prusak (1998:5): "knowledge is a fluid mix of framed experience, values, contextual information, and expert insight that provides a framework for evaluating and incorporating new experiences and information. It originates and is applied in the minds of knower's. In organisations, it often becomes embedded not only in documents or repositories but also in organisational routines, processes, practices and norms." Thus, knowledge arises as a dynamic learning process that occurs between individuals, teams, organisations and communities. Hence, SD will be explored in this paper, aligning three different structural blocks: value creation (economic growth); environment responsibility (environmental protection and eco-efficiency; and social responsibility (social progress and welfare).

Monitoring the sustainability performance indicators, associated to the existing management and measurement systems, is an important step in making the concept effective at a corporate level. As mentioned by Dudok van Heel et al. (2001) we should resolve the lack of robust measures of corporate sustainability performance. Searcy et al. (2005), in the design of a system of sustainable development, have drawn three important guidelines: 1. Indicators should be useful, both for internal and external stakeholders; 2 . Indicators should be built based on internal and external initiatives; and 3 . Existing indicators should not widely used in management decision making. Nowadays, companies usually monitor some key performance indicators in their management systems. This is the case of the sustainability reports produced and disclosed by listed companies.

Measuring the performance also appears, at a corporate level, associated to the processes of acquisition, capture, transformation, access, diffusion and re(use) of 
knowledge (Milne et al., 2009; Davenport and Prusak, 2000; Von Krogh et al., 2000; Bergstrom and Dobers, 2000). Creating insights, skills and relationships is probably the key objective of any knowledge acquisition process. However, the company's culture should be built on knowledge acquisition, sharing and use processes which drive the technology choices inside of companies. A set of metrics (financial and non-financial) is required to measure the value creation resulting from those activities.

A Balanced Scorecard (Kaplan and Norton, 1996) approach has been followed in certain companies, sometimes by adding new perspectives (environmental and social responsibilities) to the traditional framework. It provides stakeholders with a comprehensive framework that translates a company's vision and strategy into a coherent set of performance measures. These measures should be simple, widely accepted, directly linked to the three pillars of SD, and directly tied to relevant internal initiatives (Searcy et al., 2005). In order to illustrate the main key performance indicators used to monitor the structural blocks of sustainability, we present in the next topic an overview of the non-financial companies which currently integrate the Portuguese Stock Index 20 (PSI 20).

\subsection{Sustainability reporting by Portuguese listed companies}

The Lisbon Stock Exchange (LSE) was founded on $1^{\text {st }}$ January 1769, and since then, several modifications have been occurred. The merger with Euronext, agreed on January 2002, has resulted in the change of its name into Euronext Lisbon on February 6, 2002. Since this date, members of Euronext Lisbon have been given the opportunity to negotiate all products of the spot market admitted to trading on other financial markets, including Paris (Euronext Paris), Amsterdam (Euronext Amsterdam) and Brussels (Euronext Brussels). Thus, there are several Euronext indexes resulting from such transformations, in particular the index that supports part of the empirical evidence shown in this paper.

The listed companies (16 non-financial companies and 4 financial companies), currently integrating the PSI 20, report to their stakeholders, on a regular basis, sustainability information, including the activities effectively carried out. Through a content analysis to those reports, we evidence, in Fig. 2, the main vectors of sustainability. The content of these reports are normally produced using the corporate Management Information System on Sustainability, which complements the Management Information System that prepares financial information for the annual reports and accounts.

We have identified six important vectors that drive sustainability: economic value creation; environment; innovation and quality; social development; information and communication; and human resources. Broadly, companies are involved in several certification programs (v.g. PEFC-Program for the Endorsement of Forest Certification; ISO 14001 Certification, etc.), and in multiple social activities (e.g. sponsorship of culture, health, sports and social economy organizations, among others). Complementarily, most of the companies under analysis have declared biodiversity as a strategic area of their activities. Some principles are commonly addressed in their 
sustainability reports: 1) to develop biodiversity management capacity; 2) to foment knowledge about biodiversity and to strengthen collaboration between the academicscientific sector and the corporate world and 3) to implement regular and transparent reporting of the Group's performance in terms of biodiversity, verified by independent entities, as well as developing internal and external communication channels. It seems that environment issues are always included in the companies' main priorities.

All of those themes are interlinked in a cause-effect relationship despite their boundaries not clearly defined. However, listed companies have structured their sustainability reports according to the following principles and guidelines: environmental and energetic practices; social development and local communities' intervention; innovation, quality and certification; information and communication with stakeholders; human resources protection and values; and economic value creation. The identification of those main vectors supports the basis for a sustainability scorecard framework, as we will suggest in the next section.

\section{The Basis for an Sustainability Scorecard}

Balanced Scorecard (Kaplan and Norton, 1996:21) "retains financial measurement as a critical summary of managerial and business performance, but it highlights a more general and integrated set of measurements that link current customer, internal process, and employee and system performance to longterm financial success." Therefore, this tool is viewed as a measurement, communication and strategic management system using complex cause-effect chain relations (Niven, 2002). It was traditionally developed through four perspectives-financial, customer, internal processes, learning and growthand, according to available literature, it should evidence a mix of outcome measures and performance drivers, strongly aligned

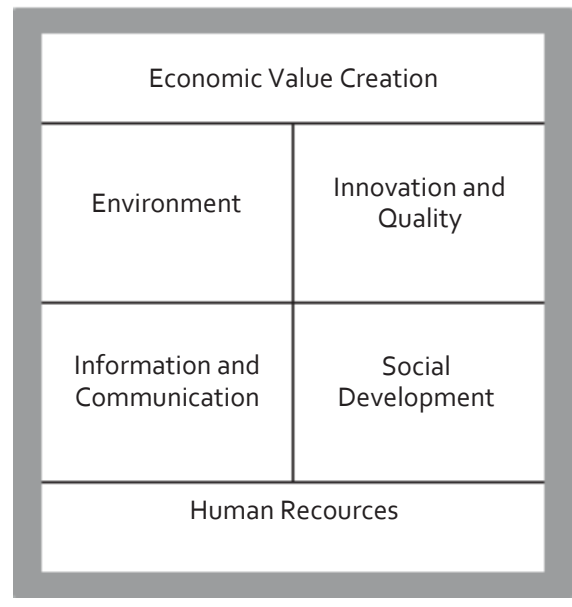

Source: Lopes, 2012

Fig. 3. Vectors of sustainability with business strategy. Broadly, as stated by Kaplan and Norton (1996), the scorecard creates a holistic model of the strategy that allows individuals and groups to capture and understand how they can contribute to organisational developments. It allows companies to align strategies, identify targets and evaluate on an on-going basis the "state-of-theart" about any particular dimension. Based on that approach, we propose in this section an integrated framework for SD monitoring, at a country and corporate level. 


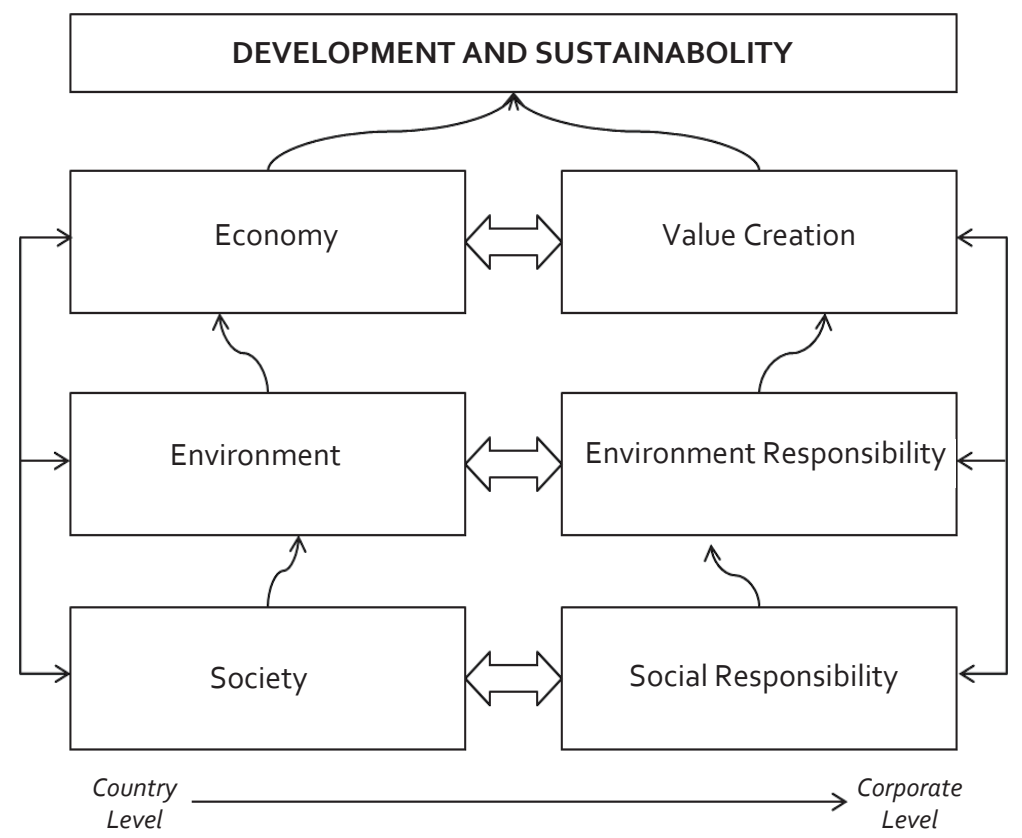

Source: Lopes, 2012

Fig. 4. A theoretical sustainability strategic map

Despite their intrinsic differences, we found a clear match between SD themes, both at a macro and micro level. However, companies define and implement strategies to grant comfortable economic and strategic positioning, in particular in relation to their direct competitors. At a macro level, sustainability is more dependent on common agreements and rules, most of them emerging within international political policies.

Parmenter (2007:203-231) has established a set of key performance indicators which can be widely used at a corporate level. Based on the PSI 20 companies, and according to their sustainability reports, we propose a set of key performance indicators, duly integrated in each sustainability theme. This framework and the set of indicators suggested have followed the balanced scorecard philosophy as stated by Kaplan and Norton (1996). As a dynamic tool, themes (perspectives) and performance indicators should be adjusted whenever news insights arise.

The development of indicators can be a complex process. Thus, it should be designed using a systematic and holistic perspective (Searcy et al., 2005:35). Internal and external expert's involvement is required in order to identify a set of indicators that really matches the stakeholders' needs. Figure 4 evidences our proposal for a sustainable development scorecard, based on the assertions stated and explored by Kaplan and Norton (1996).

The Balanced Scorecard is, in words of their creators, more than a tactical or an operational measurement system because companies use it to manage their strategies 
over their long run (Kaplan and Norton, 1996). Niven (2002:12) describe it as a "carefully selected set of measures derived from an organization's strategy." We believe that sustainability integrates, in the long run, all of these issues towards an integrated value creation process.

\begin{tabular}{|c|c|}
\hline \multicolumn{2}{|c|}{ Economic Value Creation } \\
\hline \multirow{5}{*}{$\begin{array}{l}\text { - Economic Value Added }(€) \\
\text { - Operating Costs }(€) \\
\text { - Net Operating Profit }(€) \\
\text { - Staff Costs }(€) \\
\text { - } \triangle \text { EBITDA }(\%)\end{array}$} & - Cash Value Added (€) \\
\hline & - Revenues from New Products or Services $(€)$ \\
\hline & - Gross Margin by Business (\%) \\
\hline & - Return on Net Asset Value (\%) \\
\hline & - Return on Equity (\%) \\
\hline \multirow{7}{*}{$\begin{array}{l}\text { ENVIRONMENT } \\
\text { - GHG Emissions }\left(\mathrm{tCO}_{2 \mathrm{sg}}\right) \\
\text { - Electricity and Water Consumption ( } \mathrm{GJ} \text { or } \mathrm{m}^{3} \text { ) } \\
\text { - Fuel consumption (It) } \\
\text { - Waste and Scrap Produced }(\mathrm{kg}) \\
\text { - Rate of Renewable Energy Use (\% of total } \\
\text { consumption) } \\
\text { - Investment in Electronic Documents } \\
\text { Management Systems }(€) \\
\text { - Prevention and Environmental Management } \\
\text { Costs }(€)\end{array}$} & \multirow{6}{*}{$\begin{array}{l}\quad \text { INNOVATION AND QUALITY } \\
\text { - R\&D investments (€) } \\
\text { - Certification (v.g. ISO 9001; ISO 14001, PEFC) } \\
\text { - New Products or Services (\#) } \\
\text { - Awards (\#) } \\
\text { - Investments in RDI Systems }\end{array}$} \\
\hline & \\
\hline & \\
\hline & \\
\hline & \\
\hline & \\
\hline & \multirow{2}{*}{$\begin{array}{l}\text { Social DeVeloPMENT } \\
\text { - Investments in Local Communities - } \\
\text { Donations }(€) \\
\text { - Investments in Local Communities - Public } \\
\text { Service }(€) \\
\text { - Number of Field Initiatives (\#) } \\
\text { - Investment in Promoting S. Responsibility }(€) \\
\text { - Partnership agreements (\#) } \\
\text { - Sponsorship to Sports, Culture and Science }(€) \\
\text { - Local Residents in Total Workforce (\#) }\end{array}$} \\
\hline $\begin{array}{l}\text { INFORMATION AND COMMUNICATION } \\
\text { - Investments in Knowledge Management } \\
\text { Systems }(€) \\
\text { - Informative channels with stakeholders (\#) } \\
\text { - Information Technologies Capacity (GB) }\end{array}$ & \\
\hline \multicolumn{2}{|c|}{ HUMAN RESOURCES } \\
\hline - Turnover rates (\%) & - Rate of Absenteeism (\%) \\
\hline - Average hours training per employee (h) & - Accidents at Work (\#) \\
\hline - Investments in Health and Safety $(€)$ & - Human Economic Value Added $(€)$ \\
\hline
\end{tabular}

Source: Lopes, 2012

Fig. 5. Sustainable development scorecard

\section{Final Remarks and Forthcoming Developments}

Multiple interpretations and practices can be found in the scope of sustainable development. Their boundaries are vague and their vectors are linked to multilateral cause-effect chains. The intrinsic paradox appears in the current literature as an unresolved paradigm. However, it allows us to identify its structure and to establish a systematic and dynamic framework for its performance analysis.

There is a linkage between agency theory and information management and disclosure. The information disclosed in the sustainability reports or scoreboards can influence the financial markets and other external decisions indeed. In this scope, companies tend to select the information to be disclosed, detracting the one that negatively affects their strategic and financial positioning. 
At a corporate level, sustainability is based on several strategic vectors: economic value creation, innovation and quality, social development, environment, information and communication, and human resources. However, all those pillars derive from the macro level approach. As largely cited and explained in the scientific literature, sustainability derives from three different axes: Economic growth, Environment protection and Social progress. These axes can be used as a catalyst for individual and collective change, promoting eco-efficiency, innovation and entrepreneurship.

The search for integrated knowledge management systems is also, in this field, a way ahead to value creation and for the economic sustainability achievements in the long run. Those technologies allow stakeholders for a deep integration in the entire value system and, therefore, contribute to the asymmetries mitigation.

As a dynamic tool, a scorecard will never be complete. The world (economies, environments and societies) is changing, albeit sometimes quietly, both at an international and domestic level. The framework proposed and the set of indicators suggested in this conceptual paper are just a contribution for the individual and collective mind-set, far beyond the assumptions of agency theory.

\section{Literature}

Arrow, K. (1971). Essays in the theory of risk bearing. Chicago: Markham.

Basu, A.; Lal, R.; Srinivasan, V. and Staelin, R. (1985). "Sales force compensation plans: An agency theoretic perspective", Marketing Science, 4, pp. 267-291.

Bergstrom, O.; Dobers, P. (2000). “Organizing Sustainable Development: from diffusion to translation", Sustainable Development, N. o8, pp.167-179.

Chandler, A. (1962). Strategy and structure, New York: Doubleday.

Chapman, C; Cooper, D.; Miller, P. (2009). "Linking Accounting, Organizations, and Institutions", in Chapman, C. and Miller, P. (Eds.) Accounting Organizations and Institutions, Oxford: University Press.

Crossan, M. M.; Lane, H. W. and White, R. E. (1999). "An Organizational Learning Framework: From Intuition to Institution", The Academy of Management Review, Vol. 24, no 3, pp. 522-537.
Davenport, T. H.; Prusak, L. (2000). Working Knowledge: How Organizations Manage What They Know. Boston, MA: HBSP.

Demski, J. (1980). "A simple case of indeterminate financial reporting", working paper, Stanford University.

DiMaggio, P.; Powell, W. (1991). "The Iron Cage Revisited: Institutional Isomorphism and Collective Rationality in organization fields," in: Powell, W. and DiMaggio, P. (Eds.) The New Institutionalism in Organizational Analysis, Chicago: The University of Chicago Press.

Dowling, J.; Pfeffer, J. (1975). “Organizational Legitimacy: Social Values and Organizational Behaviour", Pacific Sociological Review, 18 (1), pp.; 122-136.

Dudok Von Heel, O; Elkington, J.; Fennell, S.; Van Dijk, F. (2001). Buried Treasure: Uncovering the Business Case for Corporate Sustainability, London.

Eisenhardt, K. M. (1985). "Control: Organizational and economic approaches", Management Science, 31, pp. 134-149. 
Eisenhardt, Kathleen M. (1989). "Agency theory: an assessment and review", Academy of Management Review, Vol.14, $\mathrm{n}^{\mathrm{o}} 1$, pp. $57-74$.

Eurostat (2010). "Monitoring sustainable development in the European Union", Sigma the Bulletin of European Statistics, 2010/01. [accessed 10-09-2012],

$<$ http://epp.eurostat.ec.europa.eu/ statistics_explained/index.php/Monitoring sustainable_development_in_the_European Union>.

Fama, E. (1980). "Agency problems and the theory of the firm", Journal of Political Economy, Vol. 88, pp. 288-307.

Fontrodona, J.; Sison, A. J. G. (2006). "The Nature of the Firm, Agency Theory and Shareholder Theory: A Critique from Philosophical Anthropology", Journal of Business Ethics, 66, pp. 33-42.

Garvare, R.; Isaksson, R. (2001). "Sustainable Development: Extending the Scope of Business Excellence Models", Measuring Business Excellence, Vol. 5, n. ${ }^{\circ} 3$, pp. 11-15.

Guthrie, J.; Petty, R.; yongvanich, K. and Ricceri, F. (2004). "Using Content analysis as a Research Method to Inquire into Intellectual Capital Reporting", Journal of Intellectual Capital, 5(2), pp.: 282-293.

Jabareen, Yosef (2004). “A Knowledge map for describing variegated and conflict domains of sustainable development" Journal of Environmental Planning and Management, Vol. 47, Issue 4, pp.623-642.

Jabareen, Yosef (2008). "A new conceptual framework for sustainable development", Environment, Development and Sustainability, Vol. 10, Springer, pp.179192.

Jensen, M.; MecKLing, W. (1976). "Theory of the firm: managerial behaviour, agency costs, and ownership structure", Journal of Financial Economics, Vol. 3, pp. 305-360.

Kaplan, R. S.; Norton, D. P. (1996). The Balanced Scorecard: Translating Strategy into Action. Boston, MA: HBSP.
Kosnik, R. (1987). “Greenmail: A study in board performance in corporate governance", Administrative Science Quarterly, 32, pp. 163-185.

Kulik, B. W. (2005). "Agency Theory, Reasoning and Culture at Enron: In search of a Solution", Journal of Business Ethics, 59, pp. 347-360.

Lane, P. J.; Lubatkin, M. (1998). "Relative Absorptive Capacity and Inter-organizational Learning", Strategic Management Journal, Vol.19, pp. 461-477.

Lawrence, P.; Lorsch, J. (1967). Organization and environment, Boston: Division of Research, Harvard Business School.

Lopes, I. T.; Martins, Maria do Rosário O.; Nunes, J. M. (2005). "Towards the Knowledge Economy: the technological innovation and education impacts on the value creation process", The Electronic Journal of Knowledge Management, Volume 3, Issue 2, pp. 129-138, <http:// www.ejkm.com>.

Lopes, I. T. (2012). "Monitoring the Sustainable Development Performance: an integrated approach to business management", Contemporary challenges in the process of management in organization of the future, In Beata Domanska Szaruga and Marzena Wójcik-Augustyniak (Ed.), Warsaw, Poland: Emka Publising Company.

McGrath, J.; Martin, J.; Kukla, R. (1982) Judgment calls in research, Beverly Hills, CA: Sage.

Milne, M. J.; Tregidga, H.; Walton, S. (2009). "Words not actions! The ideological role of sustainable development reporting", Accounting, Auditing \& Accountability Journal, Vol. 22, n. ${ }^{\circ} 8$, pp. 1211-1257.

Mitnick, B. (1986). "The theory of agency and organizational analysis", University of Pittsburgh.

Moahamed, M.; Murray, A.; Mohamed, M. (2010). "The role of information and communication technology (ICT) in mobilization of sustainable development knowledge: a quantitative evaluation", Journal of Knowledge Management, Vol. 14, N. ${ }^{\circ}$, pp. $744-758$. 
Niven, P. R. (2002). Balanced Scorecard StepBy-Step: Maximizing Performance and Maintaining Results, New York: John Wiley $\&$ Sons.

Nonaka, I.; Takeuchi, H. (1995). The Knowledge Creating Company: How Japanese Companies Create the Dynamics of Innovation, New York: Oxford University Press.

Parmenter, D. (2007). Key Performance Indicators: Developing, Implementing, and Using Winning KPIs, New Jersey: John Wiley \& Sons.

Redcliff, M. R. (1987). Sustainable Development: Exploring the Contradictions, New York: John Wiley \& Sons.

Reid, G.; Smith, J. (2000). "The Impact of Contingencies on Management Accounting System Development", Management Accounting Research, 8, pp. 147-164.

Ross, S. (1973). "The economic theory of agency: The principal's problem", American Economic Review, 63, pp. 13-139.

Searcy, C.; Karapetrovic, S.; McCartney, D.(2005). "Insights from practiceDesigning sustainable development indicators: analysis for a case utility", Measuring Business Excellence, Vol. 9, № 2, pp. 33-41.

Sen, Amartya (1999). Development as Freedom, New York: Alfred A. Knopf, Inc.

Shapiro, S. P. (2005). "Agency Theory”, Annual Review of Sociology, 31, pp. 263-284.

Shapiro, C.; Varian, Hal. R. (1999). Information

Rules: A Strategic Guide to the Network
Economy, Boston, MA: Harvard Business School Press.

Spence, A. M.; Zeckhauser, R. (1971). "Insurance, information, and individual action", American Economic Review, 61, pp. 380-387.

Springett, D. (2003). "Business Conceptions of Sustainable Development: a perspective from Critical Theory", Business Strategy and the Environment, Vol. 12, pp.71-86.

Thomas, A. (1991). "Towards a Contingency Theory of Corporate Financial Reporting System", Accounting, Auditing \& Accountability Journal, 4(4), pp. 40-57.

Von Krogh, G.; Ichijo, K.; Nonaka, I. (2000). Enabling Knowledge Creation: How to Unlock the Mystery of Tacit Knowledge and Release the Power of Innovation, New York: Oxford University Press

WCED - World Commission on Environment and Development (1987), Our Common Future, Oxford: Oxford University Press.

Wenger, Etienne (1998). Communities of Practice, Cambridge: Cambridge University Press.

Wilson, R. (1968). "On the theory of syndicates", Êconometrica, 36, p.: 119-132. White, H. (1985). "Agency as control", In J. Pratt and R. Zeckhaouser (Eds.), Principles and agents: The structure of business (pp. 187-214), Boston: Harvard Business School Press.

\section{TVARIOS PLĖTROS PROCESO VERTINIMO PAVYZDYS: PERŽIANGIANT AGENTŲ TEORIJOS RIBAS}

\section{Ilídio Tomás Lopes}

Vadybos ir technologijų mokykla, Santaremo politechnikos institutas, Portugalija, ilidio.lopes@esg.ipsantarem.pt

Santrauka. Tvarios plettros koncepcija yra sudètinga ir prieštaringa. Vystymasis yra susijęs su ekonomikos bruožais ir pasiekimais, o tvarumas tradiciškai siejamas su ekologija 
ir socialine pažanga. Taigi, organizacijos turètu stebèti savo tvaraus vystymosi rodiklius, panaudodamos informacijos ir komunikacijos technologiju galimybes ir integruotas žiniu valdymo sistemas. Šiame straipsnyje mes siekeme pateikti standartizuota tvarios veiklos šablona. Remiantis literatūroje nurodytomis temomis, integruota sistema buvo pasiülyta šalies ir imoniu lygmeniu. Šios temos ir rodikliai patvirtino müsu pasiülymus dèl pagrindiniu veiklos rodikliu rinkinio, taikant subalansuotu rodikliu metoda. Šis požiūris palaiko dinamiška sistema, kuri sujungia integruota analize ir pagrindinius veiklos rodiklius siekiant tinkamai identifikuoti, agreguoti ir integruoti $i$ siüloma tvarumo rodikliu sistema. Apskritai siame straipsnyje pabrezžiama darnaus vystymosi, jo sudetingumo ribos ir pateikiama veiklos stebejimo sistema, kuri leidžia per pasirinkta rodikliu rinkini stebèti subjekto veikla. Tai dinamiška sistema, kuri gali büti koreguojama siekiant atvaizduoti tęstinius pasiekimus ir ižvvalgas šioje moksliniu tyrimu srityje. Integruotos žiniu sistemos paieška šiuo metu yra suprantama kaip büdas siekti vertès kürimo ir ekonominio bei aplinkosauginio tvarumo ilguoju laikotarpiu. Technologijos, kaip visuma, suteikia galimybe suinteresuotosioms šalims visapusiškiau isitraukti i visa vertès sistema ir taip prisideti prie informacijos asimetrijos mažinimo.

Raktiniai žodžiai: tvarumas, agentu teorija, informacijos sklaida, apskaita, veiklos rodikliai. 